Article

\title{
The Importance of Global Value Chains in Developing Countries' Agricultural Trade Development
}

\author{
Tomasz Białowąs ${ }^{1}$ and Anna Budzyńska ${ }^{2, *(D)}$ \\ 1 Department of World Economy and European Integration, Institute of Economics and Finance, \\ Faculty of Economics, Maria Curie-Sklodowska University, 20031 Lublin, Poland; \\ tomasz.bialowas@mail.umcs.pl \\ 2 Department of Microeconomics and Applied Economics, Institute of Economics and Finance, \\ Faculty of Economics, Maria Curie-Sklodowska University, 20031 Lublin, Poland \\ * Correspondence: anna.budzynska@umcs.pl
}

check for updates

Citation: Białowąs, T.; Budzyńska, A. The Importance of Global Value Chains in Developing Countries' Agricultural Trade Development. Sustainability 2022, 14, 1389.

https://doi.org/10.3390/su14031389

Academic Editors: Tomasz Kijek, Aleksandra Kowalska

Arkadiusz Kijek and

Anna Matras-Bolibok

Received: 2 December 2021

Accepted: 14 January 2022

Published: 26 January 2022

Publisher's Note: MDPI stays neutral with regard to jurisdictional claims in published maps and institutional affiliations.

Copyright: (c) 2022 by the authors. Licensee MDPI, Basel, Switzerland. This article is an open access article distributed under the terms and conditions of the Creative Commons Attribution (CC BY) license (https:// creativecommons.org/licenses/by/ $4.0 /)$.

\begin{abstract}
The role of global value-added chains is growing in international trade. The development gap between highly developed economies and developing countries means that the only products with which less developed economies can compete on the international arena are agricultural products. Moreover, integration into global value-added chains is an important factor in achieving comparative advantages in trade and improving export competitiveness. The main aim of this article is to assess the impact of integration within global value chains on changes in the comparative advantage of developing countries in the global agricultural trade. The degree of participation of developing countries in global value chains (GVC) was assessed using data from the Trade in Value-added OECDWTO database (November 2021 edition) by calculating domestic (DVA), foreign value-added (FVA), and revealed comparative advantage (RCA) indexes. The analysis covers the period 1995-2018 and 28 developing economies. The research showed that the foreign value added in the gross exports of agricultural commodities of developing countries was an important factor in strengthening their export position and the importance of integration within global value chains rises with increasing product complexity. In agricultural production, FVA in most developing countries does not have a significant impact on the shaping of the comparative advantage.
\end{abstract}

Keywords: value added chain; commodity chains; international trade; comparative advantage; revealed comparative advantage indices; developing countries

\section{Introduction}

One of the most important trends in the modern world economy is the international fragmentation of production processes and the development of global value-added chains. International trade is increasingly focused on exchanging components and intermediate goods that cross country borders many times more than final products. More than $70 \%$ of the world's exports and imports are now products that are part of global value chains, and the vast majority of which originated in manufacturing.

Global value-added chains have also emerged in the agricultural sector. Their development took place in the 1990s with the progress of the liberalization of global agricultural trade. This process began after the implementation of the Uruguay Round of GATT. It brought the economic and political transformation of the countries of central Europe, Asia and Latin America, and the growing internationalization of the activities of international corporations operating in the agricultural sector, especially food producers.

The export growth opportunities of the least developed countries (LDCs), in addition to a significant portion of developing economies, depend mainly on the potential of agriculture. Least developed countries (LDCs) have been recognized by the United Nations since 1971 as the category of the states, which "are deemed highly disadvantaged in their development process, for structural, historical and also geographical reasons" [1]. That is 
why, according to the United Nations, these low-income countries face severe structural setbacks to sustainable development [2]. Another category is developing economies, which was also introduced by the United Nations for the geographical regions: Africa, East Asia, South Asia, Western Asia, and Latin America and the Caribbean [3]. The definition of such economies is as follows "the countries that are deemed more developed are referred to as developed countries, while those that are less developed are known as less economically developed countries or frontier markets" [4]. These countries are the nations "with underdeveloped industrial base, and a low Human Development Index relative to other countries" [5]. The developmental gap in the industrial and service sectors means that agriculture is the only sector that can successfully compete with exports from economically developed countries. In most developing countries, soil, climate and human resources conditions provide a good basis for the further development of the agricultural sector. The problem, however, is the insufficient degree of mechanization, the use of plant protection products, and above all, the limited export opportunities related to the lack of integration with global production networks. The development of industry and the service sector requires much greater investment, and more importantly, is often associated with the consolidation of unfavorable specialization in labor-intensive industries. On the other hand, integration into global value chains is an important factor in improving their competitiveness in agricultural product markets. The higher the share of foreign value-added in gross exports, the stronger the integration with production and distribution networks controlled by international corporations.

Integration into global value-added chains is also an important factor in achieving comparative advantage in trade and improving export competitiveness. Since entities involved in global value-added chains are characterized by higher labor productivity and a greater propensity to export, an increase in the share of foreign value added in gross exports can positively affect their export position.

The main aim of this article is to assess the impact of integration within global value chains on changes in the comparative advantage of developing countries in the global agricultural trade. This work will verify three research hypotheses:

Hypothesis 1 (H1). Integration into global production networks contributes to the growth of export opportunities of developing countries in the agricultural sector.

Hypothesis 2 (H2). The increase in the share of foreign value added in gross exports improves the comparative advantage of developing countries in world agricultural exports.

Hypothesis 3 (H3). The importance of foreign value added in gross exports in creating a comparative advantage grows with the increase in the degree of processing of products and their capital intensity.

The position of developing countries in global agricultural trade and the degree of their integration into global production networks were analyzed in detail. The degree of participation of the analyzed group of economies in the GVC was assessed using data compiled on the basis of international input-output tables from the OECD-WTO Trade in Value-added database (November 2021 edition). The time range and number of countries included in the analysis were determined by the availability of statistical data. Therefore, the analysis covers the period 1995-2018 and 28 developing economies.

Previous analyses of value-added trade, mostly geographically, covered highly developed countries, the subject-processing industry, especially automotive, electronics, electromechanical, and the time-the period up to 2015. This article fills the existing research gap in several aspects:

(1) concerns developing countries, which so far have been poorly represented in the analysis of value-added trade, and most studies concern only the countries of the selected region; 
(2) provides an analysis of value chains in the trade in agricultural commodities, which are also relatively poorly researched compared to manufacturing industry;

(3) due to the use of the database from November 2021, the time range of the analysis was extended to 2015-2018. There are no analyses covering this period.

The earlier version of the database is from 2018. Moreover, the very use of statistics based on the value added to gross exports is a relatively new approach to the subject. The classical Balassa index was used to assess comparative advantage, but it was calculated on value-added based statistics.

The article consists of five parts preceded by an introduction (Section 1). Point 2 is a theoretical introduction to the problem of value-added trade. It presents the evolution of the approach to the concept of global value chains, taking into account the main research trends and the most important theoretical works. Section 3 conducts a literature review on global agricultural value-added chains, specifically in the context of value-added trade. Item 4 is a description of the research method. It describes the method of decomposition of gross exports (the traditional approach to trade analysis), into individual components, most importantly into domestic (DVA) and foreign value added (FVA) which are the starting points for further analysis. Then, the method of calculating the indexes of revealed comparative advantage (RCA) and interpretation of the results is discussed. The sources of statistical data are also discussed. The analytical part of the paper is Section 5, which includes a statistical analysis of agricultural trade of developing countries based on traditional statistics. Then, using the international input-output values and statistics contained in the OECD-WTO database, the importance of FVA in creating the export potential of the analyzed group of countries was calculated. It follows on to determine the evolution of their comparative advantage in world agricultural trade using both gross export data and RCA indices calculated from the domestic value added. This article ends with the main conclusions.

\section{Literature Review}

Economists agree that international production fragmentation most often benefits developing countries [6-8]. This is due to the fact that the production of goods is shared globally, while the tasks in the supply chain are dispersed between countries based on their comparative advantage. The effect is to promote trade between countries. By analyzing the data on a value-added basis, it becomes easier to observe the benefits for developing countries, as analysis on the basis of comparative advantage alone is not sufficient. This is because industrialized countries are characterized by a different level of comparative advantage from developing countries [9].

\subsection{The Concept of Global Value Chains}

International fragmentation of production details the splitting up of a previously integrated process into separate stages localized in various parts of the world. It contributes to the intensification of trade in components and intermediates. This leads to a creation of global value-added chains. The domestic value added is combined with foreign value added and the products of this process are exported and either used as inputs to final goods manufactured in other counties or sold as final products.

In the 1970s, a concept of value chains was developed. Originally, there was a term of commodity chains introduced by T. Hopkins and I. Wallerstein to develop the idea of the world system $[10,11]$. This approach evolved into global commodity chains developed by G. Gereffi and M. Korzeniewicz. The most complex take was presented in a book published in 1994 as a collection of papers from the 16th Conference on Political Economy of the World System organized in April 1992. In the introduction, G. Gereffi, M. Korzeniewicz and R. Korzeniewicz [12] explained main methodological assumptions for analysis of global commodity chains. They were characterized as networks of linkages organized around a single commodity or product than connect households, enterprises and governments within the world economy. 
The concept of commodity chains and global commodity chains was also shaped by the works of M. Porter, and his research in the global value chains, in particular. As a consequence, a term-global value chains emerged, which was initially promoted by the researchers from the Institute of Development Studies in Sussex, and later developed within wider international cooperation. G. Gereffi, J. Humphrey and T. Sturgeon [13] defined a global value chain as a process by which technology is combined with material and labor inputs, and then processed inputs are assembled, marketed, and distributed. A single firm may consist of only one link in this process, or it may be extensively vertically integrated. Instead of wide use of this term, however, there is no one settled definition in the literature for a global value chain [14]. The broad definition includes production of such goods that combines inputs from a minimum of two countries. It refers most obviously to trade in raw materials $[15,16]$, including agricultural commodities and food. By a narrower definition, the concept is limited to the complex trade of global value chains. Its evaluation takes into account only the imports used in production of export products rather than imported products for domestic consumption [17].

In recent years, the term 'global value chains' is often replaced in economic literature by the term 'global value networks', initially proposed by researchers from the University of Manchester. They pointed out that a basic weakness of the value chains of production and distribution stems from their verticality and linearity. These processes can be better explained as a network structure in which the linkages can be horizontal, diagonal and in particular vertical, creating complex, multidimensional, multi-layered economic structures [18]. Worldwide production networks are defined as the globally organized nexus of interconnected functions and operations by firms and non-firm institutions through which goods and services are produced and distributed. Such networks not only integrate firms (and parts of firms) into structures which blur traditional organizational boundaries, but also integrate regional and national economies in ways that have enormous implications for their economic outcomes [19].

\subsection{The Global Value Chains in the Agricultural Sector}

The agricultural sector is often seen primarily as a link between producers and consumers. In order to ensure adequate levels of income for the former and food security for the latter, the activities of governments were also taken into account [20-22]. However, due to difficulties in obtaining empirical data on the impact of policies on other recipients of value chains, they are often overlooked in research [23]. The entities whose role must not be ignored in research on the creation of value chains in agriculture constitute a group consisting mainly of suppliers of raw materials, food producers and traders. However, others who are involved in these processes are also important and include: landowners, seed and agrochemical companies, banks, food processors, retailers, environmental groups and the wider food trade, including final consumers, i.e., households [24]. It is worth adding that the progressive concentration in food trade further distances agricultural producers and processors from consumers, for whom they are also becoming increasingly anonymous, as direct contacts and relationships between buyers and sellers are becoming decreasingly frequent. It also reduces the quality of food, therefore quality management systems have become necessary for the proper functioning of the food chain [25]. Kowalczyk (2018) notes that the most important problem in the functioning of value chains in the agricultural commodities market is the basis for the formation of relationships between the various participants in the chains. The author lists the following factors on which these relationships are built: trust, cooperation of individual participants, creating maximum value for the final customer, or the strength of domination of individual members [26]. These considerations acknowledge the research findings of the World Bank report, which describes the negative trends associated with the strengthening of "superstar firms" [27]. The development of global value chains enables the excessive profits reaped by 'superstar companies'. These entities, in both the production and distribution spheres, increase their market shares and benefits, subsequently increasing their market dominance. They managed to obtain such dominance owing to their resources 
for implementing innovative technological changes [28]. Companies that are less involved in global value chains lose their importance in the market and earn lower profits, which translates into lower investment capacity [29]. As a result, their long-term functioning on the global market is at risk. To improve operating prospects, non-superstar entrepreneurs from developed countries are partnering with suppliers from developing countries [30]. In the 1960s, the French National Institute of Agricultural Research (INRA) together with the Centre for International Agricultural Research for Development (CIRAD) developed the concept of agricultural commodity chains. The term was created to describe the processes characterizing the production and distribution of agricultural commodities [31,32]. It contains components that make up the concept in question: inputs and products, costs, prices and added value $[33,34]$. The development of the concept has evolved towards the development of companies' competitiveness. Enterprises operating within global value chains on the market of agricultural products should analyze the basic activities, which include: logistics and marketing as well as supporting activities in the field of using the company's infrastructure, resources and technologies [35]. Further development of the described concepts expanded the set of elements and processes included in global commodity chains of agricultural commodities [36]. Gerefii (1994) proposed three dimensions based on the international development of production, trade and distribution as well as networks exporting agricultural products between different countries [37]. Subsequent researchers developed various perspectives and their relations between the described dimensions and supplemented them with new aspects [38-40].

Another aspect was shown by Lim's (2020) research which analyzed how the participation in global agricultural value chains has changed the nature of agricultural production around the world wherein the different stages of the production process are located across different countries. During research, the results obtained indicated that as countries participated in agricultural global value chains, they transformed their economies. That transformation is taken from the agricultural sector directly to the service sector, leapfrogging the manufacturing sector. This conclusion was reached by using multi-region input-output data for 183 countries for the period 1990-2013. On this basis, the author concluded that trade liberalization through agricultural global value chains helped support structural transformation of modern agrarian economies. This has been identified as a key driver of sustainable economic growth [41]. Tinta et al. (2018) highlighted the need to strengthen and better promote regional integration, with which it is inherent to achieve advantages from the growth of global value chains. As a result of their work, an acceleration in economic growth on the one hand and, on the other hand improvement of food security occurred [42]. Other estimates (Yanikkaya, Karaboga, Altun 2021) have indicated the strong relationship between participation of a county or sector's share in global value chains and its position in international trade networks. The more trade links or forms of cooperation, the stronger the trade position of a country or sector possesses [43]. Trade within global value chains is characterized by the deep level of specialization needed to achieve high productivity or intra-firm trade within multinational enterprises, which can be difficult to replace or substitute [44]. The benefit achieved from participation in global value chains is the use of comparative advantages of co-operators. Additionally, a chain of interconnected production units, located in different parts of the world, generates added value at each stage of the entire production process. Therefore, global value chains are important structures in the world trade and investment process, affecting the economic development of the local economy in the host country. Today, GVCs account for almost $50 \%$ of global trade. If GVC activity increases by $1 \%$, the per capita income level of the host country increases by more than $1 \%$. This is about twice the impact on the host economy over conventional previous international trade relations [45]. The benefits of taking part in the global value chains, which can be observed in small farms have been linked with modernization. These changes are concerned with using new cultivation methods and production processes, which gives effective tools for empowerment and poverty reduction [46]. Dollar, Khan and Pei (WTO 2019) noted that participation in global value chains 
makes it easier for developing countries to independently export unprocessed products and to start specializing in a specific trade branch by joining a global production network. After several years of a developing country's participation in global value chains, there is a reduction in the ratio of domestic value added to gross export value [47]. In this way, participation in global value chains has shaped production and specialization worldwide and, in all sectors, including agriculture and the food sector [48]. This has enabled even small countries with limited capacity or resources to have a chance to participate in the GVC and enjoy the benefits of global trade [49-52]. Although the agricultural sectors are involved in value chains primarily as suppliers of raw materials used in other production processes [53]. Few companies are involved in the global food supply. In addition, few small producers in developed countries supply agri-food products to consumers around the world [54,55].

In contrast, the impact of participation in regional trade agreements was examined by Sanguinet, Alvim and Atienza (2021). The authors of the study found that the deepest trade agreements reinforced the position of suppliers, even from lower technology industries [56]. Although these studies were conducted in Latin American countries, their conclusions can be generalized because Chinese companies participate in global value chains precisely through trade agreements [57]. However, Chinese traders are still in the low part of global value chains as transnational corporations control exchanges in the higher valueadded parts. In China, above all, but also in other producers from developing countries, trade networks should be modernized and the domination of transnational corporations reduced [58]. Unlike Latin American and Asian countries, sub-Saharan African countries are not deeply integrated into global production networks, and thus have a significantly limited share of global value chains. However, research by Balie et al. (2019) proved that the share of food and agricultural products from these countries in gross exports was significant. Therefore, they recommend including this part of trade in the priorities of government trade policies [59]. In this context, important findings were presented by Hidayati, Garnevska and Childerhouse (2021). The authors noted a regularity that applies to entities involved in international trade in agri-food commodities from developing countries. Compliance of the products offered with quality and food safety standards is a prerequisite for handling high-value global chains of the items in question. They therefore recommended focusing on marketing that has been promoted small ecological farmers [60]. Other researchers recommend the relationships in global value chains, on the basis of which it will be possible to use resources related to the complementarity of manufactured goods and the synergistic effects achieved [61].

\subsection{The Role of Value Added in Comparative Advantage}

Synergy is not the only benefit that arises from participating in global value chains. Many international factors play a significant role in value-added growth, especially in agriculture. Karadimitropoulou argues that these factors account for the variability of between $30 \%$ and $60 \%$ of agricultural value-added growth in some countries [62]. Becvarova, on the other hand, noted that the globalization processes so affect the entire international system of food production, processing and distribution that they also change the creation of added value in agriculture [63]. The value added can also be a measure of a product's competitiveness. In this case, there is a relationship according to which the higher the added value of the product, the greater its competitiveness [64]. The use of foreign value added in the creation of comparative advantage in global exports also plays an important role [65]. The comparative advantage introduced by Ricardo is used for value added in exports where there are no intermediate inputs imported from various industries in many countries. Therefore, it works perfectly for agricultural trade. The coefficients estimated by Choi and Park (2016) allow the conclusion that comparative advantage is better defined as patterns for world trade with global value chains [66]. If, on the other hand, Revealed Comparative Advantage (RCA) indices are used as measures of competitiveness, the conclusions may differ from those obtained when examining only the indicators based 
on the gross export values [67]. A study by Wang, Wei and Zhu (2013) obtained lower values of revealed comparative advantages (RCA) indices based on the value added for India than indices based on gross export value alone. In contrast, Deb and Hauk (2017), when considering analogous indices for Germany, obtained significantly higher values of revealed comparative advantages (RCA) indices [68]. Grater (2014), who conducted a study of comparative advantages in terms of the value added in relation to gross exports for South Africa, received higher values for comparative advantage [69].

Research on comparative advantages and the increased interest of agri-food sector entities in improving competitiveness result from participation in global value chains. The benefits for the sector in general are related to specialization and openness to trade. On the other hand, this has a positive effect on the creation of national added value. This was especially beneficial for suppliers from Latin America and Asia, whose semi-finished products are often increasingly processed and sold in regional networks [70].

\section{Methods and Data Sources}

In terms of methodology, the basic assumption in trade analyses based on value added to gross exports is the ability to assess the domestic contribution to the final value of the product. Let us assume that (disregarding taxes and subsidies for the sake of simplification) value of the final product (VP) equals the sum of value added (VA) during the production process in following countries. The formula is (1).

$$
\mathrm{VP}=\sum_{\mathrm{i}} \mathrm{VAP}_{\mathrm{i}}
$$

Country A net value added (NVA), which constitutes a trade balance, is a difference between gross exports and gross imports (2).

$$
\mathrm{NVA}=(\mathrm{DVA}+\mathrm{FVA})-(\mathrm{BVA}+\mathrm{RVA}+\mathrm{MVA})
$$

Gross exports constitute a sum of domestic direct and indirect value added (DVA), which is being exported by Country A to other countries and also foreign value added (FVA), which includes previously imported foreign components, parts and raw materials used in the production process (Figure 1). Domestic value added can be deconstructed into the absorber abroad part, which includes final goods and services, intermediate exports absorber by the direct importer as well as intermediates sent to the first importer then re-exported to the third country in addition to value added that was first exported and then returned home. Foreign value added can be contained in final exports or in intermediate exports. The final category included in gross exports is double-counted exports which comprise of the same products (both foreign and domestic) exported twice or more times. 


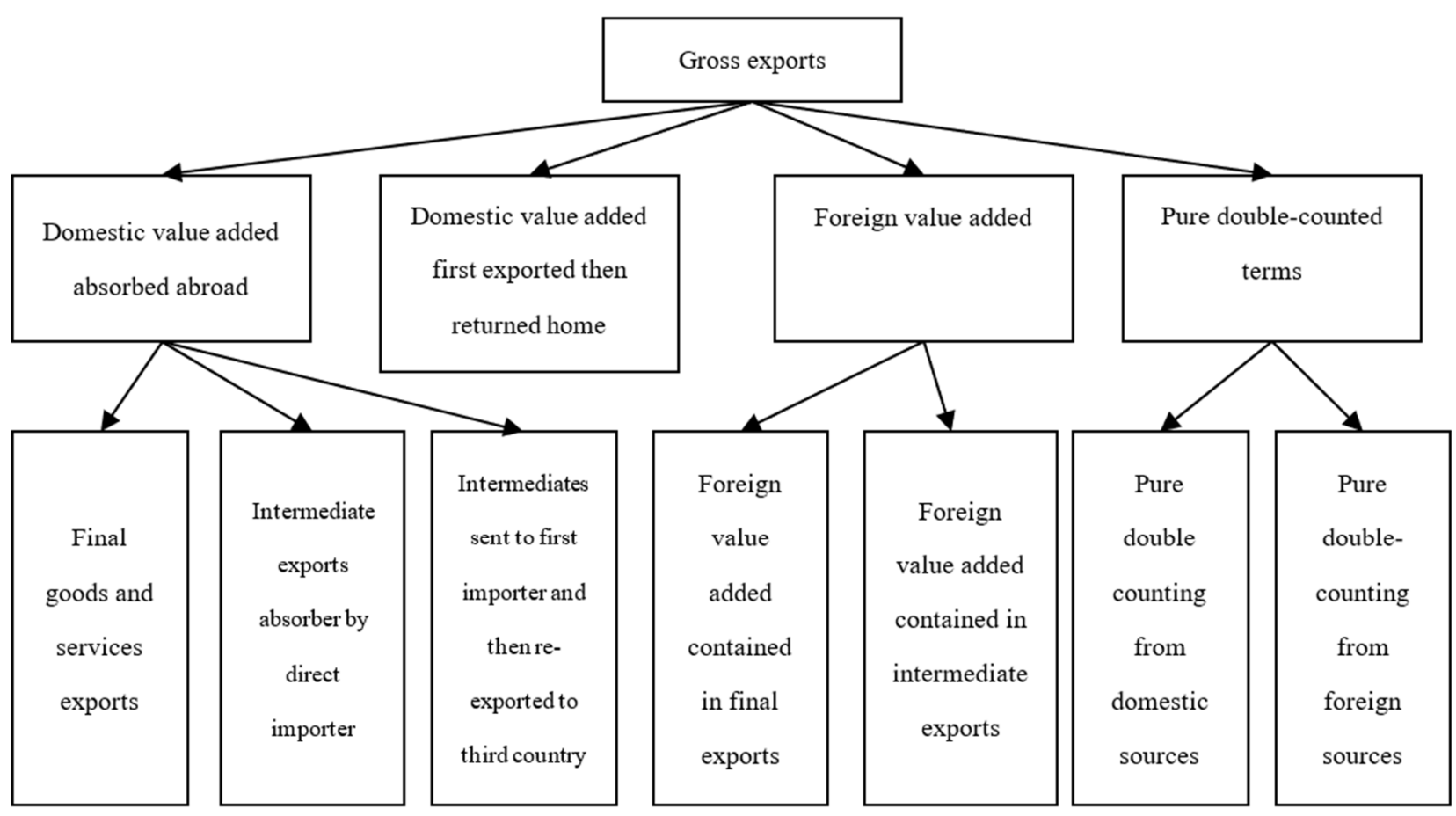

Figure 1. Measuring gross exports. Source: [71].

The standard measure used to assess comparative advantage in world exports is Balassa index [72]. The Balassa index is defined as the ratio of a country's share in world exports of a given industry divided by its share of overall world trade. More specifically, $B I_{j}^{A}$ is country A's Balassa index for industry $j$ defined as in Formula (3). That is a ratio of the share of industry $j$ in country A exports $\left(s_{j}^{A}\right)$ and the share of industry $j$ in reference to country R exports $\left(s_{j}^{R}\right)$. If $B I_{j}^{A}>1$, country A is said to have a revealed comparative advantage (RCA) in industry $j$, since this industry is more important for country A's exports than for the exports of the reference countries.

$$
B I_{j}^{A}=\frac{s_{j}^{A}}{s_{j}^{R}}
$$

Developing countries' comparative advantage in international trade based on RCA indexes can be calculated in a traditional way using value of gross exports or in an alternative way-using domestic value added. In the first approach RCA value is determined by country's integration with international production networks and foreign value added. The second approach allows one to view in a more objective way the real comparative advantage in world exports.

There are several primary sources of statistical data containing information on trade in value added. Among the most important, we can mention the EORA26 database [73], which was created on the initiative of UNCTAD and contains statistical data for the years 1990-2018. Another project, the WIOD database [74], is being developed by a consortium of universities and research institutes from Europe. The latest edition from November 2021 contains data on sources of added value for 43 countries and the rest of the world for the period 1995-2018. The third project of Asian Development Bank MRIO 2021 covers data for the years 2000 and 2007-2020. The last database used for the calculations in this article is a joint project of the WTO and OECD [75]. The current 2021 edition covers 64 economies (including all OECD, EU, and G20 countries and most East and Southeast Asian economies) and region aggregates. Indicators are available for 36 industries within a hierarchy based on ISIC Rev. 4. It contains data for 1995-2018. 


\section{Results and Discussion}

\subsection{The Position of Developing Countries in World Agricultural Trade}

The value of world food exports during the 26-year period under review, i.e., 1995-2020, more than tripled (averaging about $13.2 \%$ per year), while the increase in the value of food exports from developing countries reached almost five times its initial value, growing by less than $18 \%$. Thus, the share of food exports from developing countries in world trade increased (Figure 2) [76].

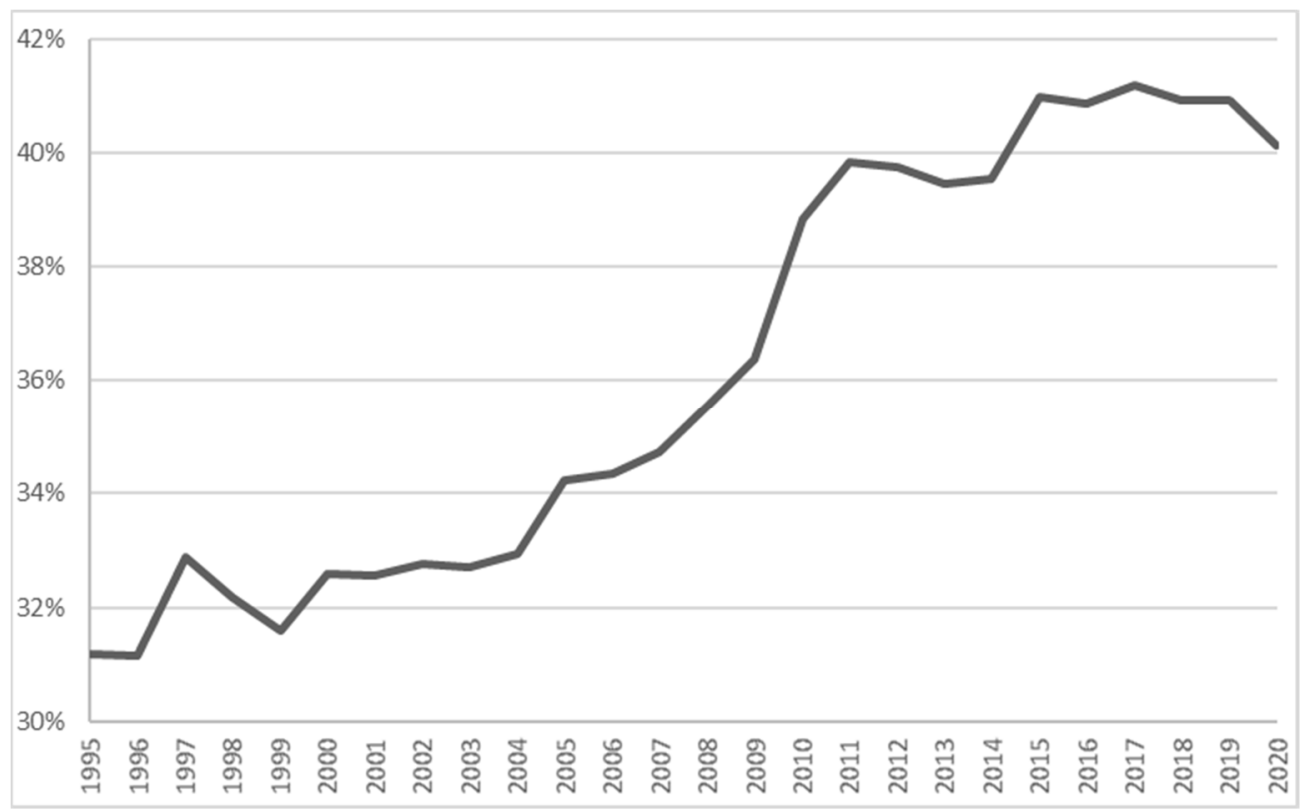

Figure 2. Share of developing countries in world food exports in the years 1995-2020. Source: UNCTAD Database, https: / / stats.unctad.org/ (accessed on 30 November 2021).

The share of developing countries in world food exports has been on a steady upward trend. In the second half of the 1990s it oscillated around 32\%, while after 2010 it reached almost $40 \%$. The average annual share of food exports from developing countries was $36.2 \%$ between 1995 and 2020, of which until 2008 the share was below the average level, and since 2009 the value of the share of food exports from developing countries has exceeded the average values. In 2017, developing countries accounted for the largest share of global food exports at $41.2 \%$.

The increase in the share of developing countries in world food exports between 1995 and 2020 was 9\%. The largest part of exported food (average share in the period under review was $19.2 \%$ per year) came from the Asian continent together with Oceania, and this group also saw the largest increase in the share of food exports supplied to foreign markets. Latin and South American food exporters also held a significant share at an average annual rate of $13.7 \%$, increasing their share of global food exports by over $3 \%$. On the other hand, the share of food export from African countries remained stable (Table 1).

Table 1. Share of developing countries in world food exports in the years 1995-2020.

\begin{tabular}{cccccccc}
\hline Country & $\mathbf{1 9 9 5}$ & $\mathbf{2 0 0 0}$ & $\mathbf{2 0 0 5}$ & $\mathbf{2 0 1 0}$ & $\mathbf{2 0 1 5}$ & $\mathbf{2 0 2 0}$ & Change 1995-2020 \\
\hline Developing countries & $31.2 \%$ & $32.6 \%$ & $34.3 \%$ & $38.9 \%$ & $41.0 \%$ & $40.1 \%$ & 9.0 \\
Africa & $3.7 \%$ & $3.4 \%$ & $3.4 \%$ & $4.0 \%$ & $3.9 \%$ & $3.7 \%$ & 0 \\
Latin and South America & $11.3 \%$ & $12.6 \%$ & $13.7 \%$ & $14.7 \%$ & $14.7 \%$ & $14.6 \%$ & 3.3 \\
\hline
\end{tabular}


In world agricultural commodity exports, the share of developing countries was in the range of $28-41 \%$ between 1995 and 2020, reaching an annual average value of $34 \%$. From 2001 to 2011, the share of agricultural commodity exports from developing countries described an upward trend, which then collapsed. In 2013, the share declined by $2.5 \%$ over the 1-year period and by a further $1.3 \%$ over the following year. A return to an upward trend has occurred since 2017, but has not reached the 2011-2012 peaks (Figure 3).

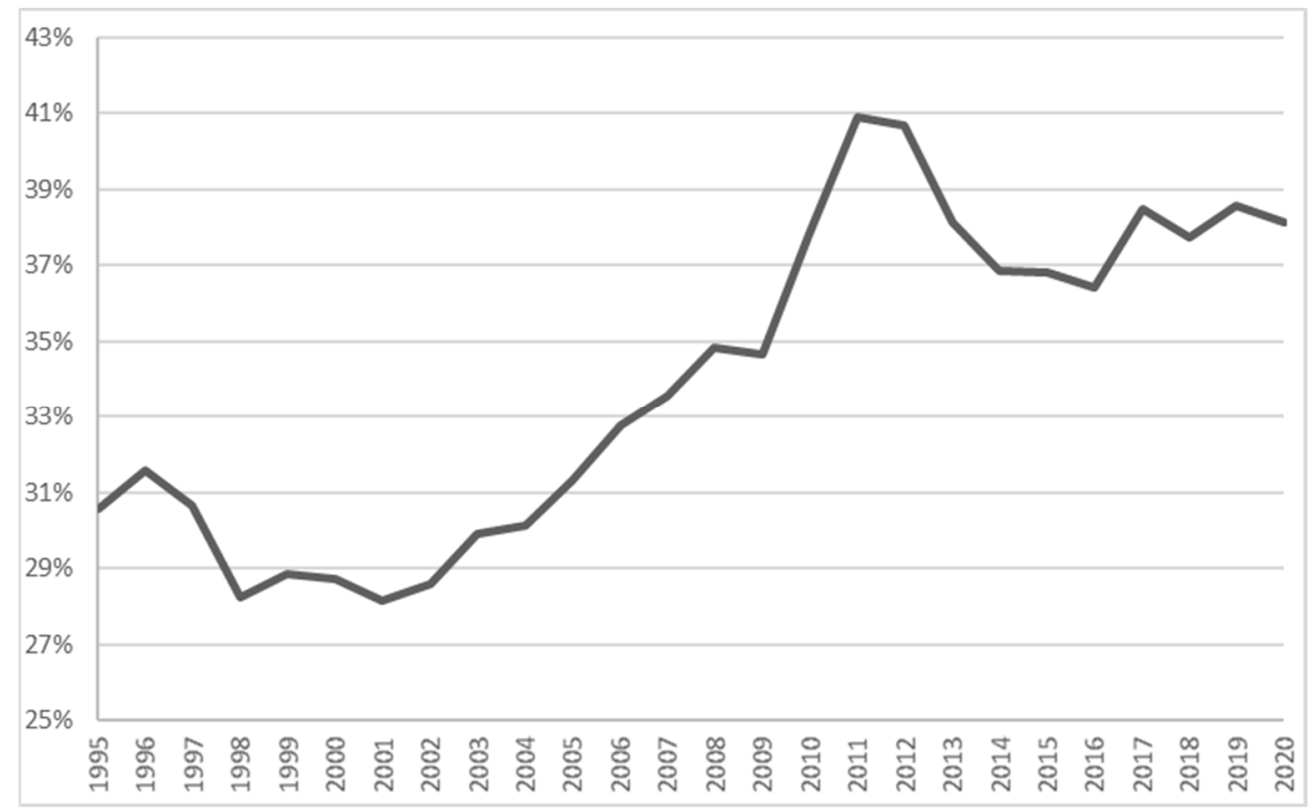

Figure 3. Share of developing countries in agricultural raw materials exports in the years 1995-2020. Source: UNCTAD Database, https:/ / stats.unctad.org/ (accessed on 30 November 2021).

In the case of trade in agricultural commodities, the Asian continent with Oceania had the largest share in world exports, averaging 23.6\% per year between 1990 and 2020. The highest increase (reaching almost $4 \%$ ) in the share of exported agricultural raw materials belonged to exporters from Latin and South America, while African exporters kept their share in the export of agricultural raw materials constant, averaging about $4.3 \%$ per year (Table 2).

Table 2. Share of developing countries in agricultural raw materials exports in the years 1995-2020.

\begin{tabular}{cccccccc}
\hline Country & $\mathbf{1 9 9 5}$ & $\mathbf{2 0 0 0}$ & $\mathbf{2 0 0 5}$ & $\mathbf{2 0 1 0}$ & $\mathbf{2 0 1 5}$ & $\mathbf{2 0 2 0}$ & Change 1995-2020 \\
\hline Developing countries & $30.6 \%$ & $28.7 \%$ & $31.3 \%$ & $37.8 \%$ & $36.8 \%$ & $38.2 \%$ & 7.6 \\
Africa & $4.3 \%$ & $4.3 \%$ & $4.6 \%$ & $4.2 \%$ & $4.2 \%$ & $4.6 \%$ & 0.3 \\
Latin and South America & $6.4 \%$ & $6.6 \%$ & $7.1 \%$ & $7.6 \%$ & $8.7 \%$ & $10.2 \%$ & 3.8 \\
\hline
\end{tabular}

Source: UNCTAD Database, https: / / stats.unctad.org/ (accessed on 30 November 2021).

\subsection{The Importance of Foreign Value Added in the Gross Exports of Agricultural Commodities of Developing Countries}

The standard method of assessing the degree of a country's participation in global value-added chains is to estimate the share of foreign value added in gross exports. Using the data contained in the OECD-WTO database, we can determine the share of foreign value added in gross exports of agriculture, hunting, forestry, fishing, food products, beverages and tobacco of 28 developing countries in 1995-2018 (Table 3). 
Table 3. Foreign value-added share of gross exports in agriculture, hunting, forestry and fishing in the years 1995-2018.

\begin{tabular}{|c|c|c|c|c|c|c|}
\hline Time & \multirow{2}{*}{1995} & \multirow{2}{*}{2000} & \multirow{2}{*}{2005} & \multirow{2}{*}{2010} & \multirow{2}{*}{2015} & \multirow{2}{*}{2018} \\
\hline Country & & & & & & \\
\hline \multicolumn{7}{|c|}{ Asia and Oceania } \\
\hline Cambodia & 4.59 & 6.15 & 8.87 & 10.82 & 8.96 & 8.65 \\
\hline China (People's Republic of) & 2.21 & 5.60 & 8.03 & 7.57 & 7.25 & 9.44 \\
\hline India & 1.00 & 1.44 & 2.81 & 3.72 & 3.41 & 4.10 \\
\hline Indonesia & 5.24 & 7.62 & 9.80 & 4.01 & 4.81 & 6.06 \\
\hline Kazakhstan & 20.27 & 24.00 & 19.63 & 13.63 & 7.66 & 10.60 \\
\hline Lao People's Democratic Rep. & 14.87 & 18.62 & 11.50 & 16.01 & 8.98 & 8.24 \\
\hline Malaysia & 19.19 & 20.33 & 18.57 & 16.22 & 14.17 & 14.80 \\
\hline Myanmar & 6.03 & 7.60 & 2.40 & 2.41 & 4.35 & 5.32 \\
\hline Philippines & 8.78 & 7.59 & 9.77 & 6.61 & 5.79 & 7.38 \\
\hline Thailand & 9.54 & 14.38 & 19.44 & 18.01 & 15.78 & 14.22 \\
\hline Turkey & 1.73 & 2.31 & 4.71 & 6.00 & 10.84 & 15.97 \\
\hline Vietnam & 16.15 & 20.46 & 26.29 & 28.90 & 31.93 & 35.61 \\
\hline \multicolumn{7}{|c|}{ Africa } \\
\hline Morocco & 9.57 & 10.62 & 11.84 & 16.30 & 12.99 & 13.31 \\
\hline South Africa & 9.19 & 11.69 & 13.61 & 15.95 & 21.88 & 21.06 \\
\hline Tunisia & 4.35 & 6.70 & 6.81 & 14.77 & 9.03 & 11.47 \\
\hline \multicolumn{7}{|c|}{ Europe } \\
\hline Bulgaria & 6.70 & 12.80 & 17.76 & 26.16 & 26.35 & 27.31 \\
\hline Croatia & 16.76 & 18.32 & 21.95 & 19.00 & 22.25 & 21.42 \\
\hline Hungary & 13.44 & 24.68 & 25.90 & 28.46 & 27.47 & 27.63 \\
\hline Poland & 10.07 & 18.69 & 20.29 & 20.73 & 23.85 & 25.23 \\
\hline Romania & 3.93 & 6.54 & 8.50 & 17.72 & 16.74 & 17.50 \\
\hline Russian Federation & 9.82 & 11.51 & 10.37 & 10.72 & 9.86 & 11.11 \\
\hline \multicolumn{7}{|c|}{ South and Central America } \\
\hline Argentina & 2.30 & 2.56 & 6.37 & 5.92 & 4.99 & 5.98 \\
\hline Brazil & 3.80 & 6.47 & 7.56 & 7.56 & 10.66 & 10.40 \\
\hline Chile & 12.40 & 14.97 & 18.37 & 15.75 & 13.83 & 14.30 \\
\hline Colombia & 7.02 & 7.79 & 7.99 & 6.53 & 9.70 & 8.89 \\
\hline Costa Rica & 12.75 & 17.10 & 16.55 & 16.43 & 17.14 & 19.22 \\
\hline Mexico & 4.83 & 7.07 & 7.90 & 9.11 & 10.78 & 11.65 \\
\hline Peru & 5.00 & 5.14 & 5.85 & 4.98 & 4.30 & 4.10 \\
\hline
\end{tabular}

Based on the data contained in the Table 3, we can draw some conclusions. First, the share of foreign value added in agriculture, hunting, forestry and fishing exports varied widely between countries. The highest share of FVA in 2018 was that of Vietnam (35.61\%), Hungary (27.63\%), Bulgaria (27.31\%), Poland (25.23\%), and Croatia (21.42\%). In other countries, the share of foreign value added in gross exports did not exceed $20 \%$. Particularly weak links within global value chains, in which the share of FVA did not exceed $10 \%$ of gross exports, occurred in several Asian economies (Cambodia, China, India, Indonesia, Lao, Myanmar, Philippines) and South and Central America (Argentina, Colombia and Peru).

Secondly, when analyzing the changes in the strength of production links in agriculture, hunting, forestry and fishing after 1995, several trends can be identified. First of all, there are clear differences between the continents. In the case of Europe and Latin America, we can observe an increase in the share of foreign expenditure in exports, especially rapid in Europe in the years 1995-2010. After 2010, the growth dynamics weakened, which may be related to the phenomenon of defragmentation of production chains after the economic and financial crisis of 2008-2009. More complex changes took place in the countries of Asia and Oceania. Only in the case of Turkey and Vietnam has there been a steady increase in the strength of production links. 
In Turkey, the share of foreign value added in gross exports increased by $14 \%$, and in Vietnam by 19\%, which was one of the best results in the studied group of developing countries. In other Asian countries, the trends in the share of FVA were variable. In Cambodia and India, the share of FVA grew until 2010, in China, Indonesia and Thailand until 2005, in Kazakhstan, Malaysia and Myanmar until 2000. In the following years, there was an extension to 2015 (Indonesia, Myanmar) or even 2018 (China, India, Kazakhstan, Malaysia), the weakening of production ties. The Philippines was characterized by the greatest volatility of the trends, but downward trends prevailed there. In Africa, the share of foreign value added in gross exports of agriculture, hunting, forestry and fishing increased in the years 1995-2010 (in the case of South Africa until 2015), and in the following years the production links weakened.

The second product groups analyzed were beverages and tobacco (Table 4). Since the degree of processing of these goods is higher than that of unprocessed food and agricultural raw materials, the share of foreign value added in gross exports is also higher. The strongest manufacturing linkages characterize Vietnam (FVA's share of gross exports was $40.71 \%$ in 2018), Hungary (38.18\%), Bulgaria (35.70\%), Malaysia (31.93\%), and Tunisia (30.41\%). In contrast, the lowest share of FVA was characteristic for some economies in Asia (China, India, Indonesia, Myanmar) and South America (Argentina, Brazil). As in the previously analyzed group of unprocessed agricultural products, and in the case of processed foods, there were large differences in the strength of production linkages within global value chains between continents during 1995-2018. In Europe, the share of foreign intermediate goods in gross exports was the highest, in addition to showing an upward trend, except for Croatia and Russia, where the share of FVA remained relatively stable. In South and Central America, linkages within global value-added chains developed until the first half of the 2000s. They weakened between 2005 and 2010 and especially 2009 and 2010, and since 2015 the share of FVA has stabilized. In Asian countries, production linkages in food products, beverages and tobacco expanded in Turkey and Vietnam throughout the period under review (1995-2018), and remained stable and strong in the Philippines. In the other economies, FVA's share of gross exports grew until the crisis period of 2008-2009 and then fell by a few percent and, in the case of Cambodia, 12 percent. In Africa, stable production links were characteristic of Morocco (the share of FVA in gross exports oscillated around $20 \%$ in the period under review). South Africa and Tunisia have generally followed an upward trend in the share of FVA in gross exports.

Table 4. Foreign value-added share of gross exports in food products, beverages and tobacco.

\begin{tabular}{|c|c|c|c|c|c|c|}
\hline Time & \multirow{2}{*}{1995} & \multirow{2}{*}{2000} & \multirow{2}{*}{2005} & \multirow{2}{*}{2010} & \multirow{2}{*}{2015} & \multirow{2}{*}{2018} \\
\hline Country & & & & & & \\
\hline \multicolumn{7}{|c|}{ Asia and Oceania } \\
\hline Cambodia & 24.82 & 31.98 & 37.06 & 21.77 & 24.97 & 23.02 \\
\hline China (People's Republic of) & 7.52 & 8.71 & 10.32 & 10.59 & 9.03 & 10.52 \\
\hline India & 2.20 & 3.52 & 5.64 & 7.07 & 7.58 & 8.76 \\
\hline Indonesia & 9.20 & 11.40 & 12.09 & 7.74 & 8.47 & 9.50 \\
\hline Kazakhstan & 20.23 & 25.09 & 20.67 & 15.38 & 11.82 & 13.07 \\
\hline Lao People's Democratic Rep. & 23.78 & 29.41 & 16.94 & 22.62 & 14.52 & 14.01 \\
\hline Malaysia & 30.73 & 33.09 & 32.73 & 30.07 & 31.77 & 31.93 \\
\hline Myanmar & 6.95 & 10.93 & 3.02 & 2.84 & 5.23 & 6.41 \\
\hline Philippines & 20.42 & 13.18 & 14.33 & 11.79 & 11.58 & 14.69 \\
\hline Thailand & 16.66 & 20.92 & 26.04 & 23.39 & 22.59 & 21.04 \\
\hline Turkey & 5.83 & 8.54 & 9.97 & 11.86 & 13.53 & 17.04 \\
\hline Vietnam & 19.56 & 25.54 & 34.40 & 34.58 & 37.15 & 40.71 \\
\hline
\end{tabular}


Table 4. Cont.

\begin{tabular}{|c|c|c|c|c|c|c|}
\hline Time & \multirow{2}{*}{1995} & \multirow{2}{*}{2000} & \multirow{2}{*}{2005} & \multirow{2}{*}{2010} & \multirow{2}{*}{2015} & \multirow{2}{*}{2018} \\
\hline Country & & & & & & \\
\hline \multicolumn{7}{|c|}{ Africa } \\
\hline Morocco & 19.17 & 19.56 & 20.94 & 21.39 & 19.20 & 20.89 \\
\hline South Africa & 9.67 & 12.47 & 13.38 & 13.91 & 16.79 & 14.78 \\
\hline Tunisia & 21.81 & 22.04 & 24.77 & 30.99 & 27.87 & 30.41 \\
\hline \multicolumn{7}{|c|}{ Europe } \\
\hline Bulgaria & 11.47 & 20.41 & 23.15 & 29.78 & 32.74 & 35.70 \\
\hline Croatia & 23.20 & 25.97 & 27.73 & 24.34 & 26.99 & 26.61 \\
\hline Hungary & 17.58 & 30.80 & 31.86 & 35.70 & 38.33 & 38.18 \\
\hline Poland & 9.63 & 18.25 & 20.37 & 21.96 & 25.71 & 27.46 \\
\hline Romania & 6.65 & 8.94 & 9.97 & 14.95 & 17.06 & 17.45 \\
\hline Russian Federation & 15.92 & 16.62 & 14.99 & 15.73 & 16.20 & 15.58 \\
\hline \multicolumn{7}{|c|}{ South and Central America } \\
\hline Argentina & 3.36 & 3.76 & 7.79 & 7.15 & 5.67 & 7.17 \\
\hline Brazil & 6.56 & 10.86 & 9.50 & 9.13 & 11.50 & 11.27 \\
\hline Chile & 14.29 & 16.25 & 18.01 & 18.14 & 15.26 & 15.41 \\
\hline Colombia & 13.60 & 9.96 & 9.91 & 9.84 & 14.31 & 13.48 \\
\hline Costa Rica & 18.93 & 23.21 & 25.29 & 21.44 & 20.53 & 21.80 \\
\hline Mexico & 32.42 & 38.75 & 35.08 & 29.54 & 24.73 & 25.43 \\
\hline Peru & 13.08 & 13.37 & 14.32 & 14.17 & 14.04 & 14.00 \\
\hline
\end{tabular}

Source: OECD, Trade in Value-added (TiVA) 2021 ed., http:/ / stats.oecd.org/ (accessed on 30 November 2021).

\subsection{The Comparative Advantage in International Trade of Agricultural Commodities}

The standard method of assessing comparative advantage in international trade is based on the classical indexes of revealed comparative advantage (RCA). Based on data in terms of gross and domestic value added, we can determine the impact of integration within global value-added chains on competitive advantage in trade. In Table 5, the results of the RCA indices in agriculture, hunting, forestry and fishing are included. In the traditional approach to gross exports (GE), Colombia (14.04), Myanmar (12.35), Costa Rica (9.75), Argentina (6.85), and Lao (6.19) had the highest comparative advantage in 1995. In the remaining analyzed economies RCA indices did not exceed 5, and Poland and the Russian Federation showed a gap. By 2018, there were significant changes in the evolution of revealed comparative advantage. RCA rates increased in 5 Asian countries (Cambodia, Indonesia, Kazakhstan, Lao and Vietnam), 3 in Europe (Bulgaria, Romania and Russia), 2 in South and Central America (Brazil and Mexico) and in Tunisia. In the remaining countries analyzed, the comparative advantage declined or a gap emerged (China, India, Malaysia, Thailand). In 2018, Myanmar (10.67), Brazil (9.14), Lao (7.58), Costa Rica (6.33) and Argentina (5.76) showed the highest comparative advantage.

Evaluation of the assessment of comparative advantage on RCA indices calculated on the basis of the gross value of exports may distort the actual specialization of individual economies. Only clearing gross exports of foreign value added and calculating the RCA indices taking into account only the domestic value added, allows the obtainment of objective results showing the real comparative advantage of the assessed countries. In 1995, countries such as Colombia (14.70), Myanmar (14.48), Costa Rica (10.92), Argentina (6.92) and Lao (6.66) had the highest comparative advantage calculated on the basis of domestic value added to gross exports. In other countries, RCA indices did not exceed 5, and only in the cases of Poland and the Russian Federation were they lower than 1 , which means a comparative gap in this sector. As with the RCA indices calculated on the basis of gross export (GE), after the additional application of the alternative calculation method, until 2018, there were some changes in the evolution of the comparative advantage of the assessed countries. RCA indices increased in 2 countries of South and Central America (Brazil and Mexico), 4 Asian countries (Cambodia, Indonesia, Lao and Vietnam), 2 European countries (Bulgaria, Romania and Russia) and 2 African countries (Morocco 
and Tunisia). In 2018, Myanmar (11.86), Brazil (9.12), Lao (8.31), Costa Rica (6.09) and Argentina (5.88) had the highest comparative advantage calculated on the basis of domestic value added to gross exports.

Table 5. RCA based on national added value in agriculture, hunting, forestry and fishing.

\begin{tabular}{|c|c|c|c|c|c|c|}
\hline & \multicolumn{2}{|c|}{ DVA } & \multicolumn{2}{|c|}{ GE } & \multicolumn{2}{|c|}{ GE-DVA } \\
\hline & 1995 & 2018 & 1995 & 2018 & 1995 & 2018 \\
\hline Chile & 4.10 & 2.81 & 4.18 & 2.90 & 0.08 & 0.09 \\
\hline Colombia & 14.70 & 3.51 & 14.04 & 3.48 & -0.66 & -0.03 \\
\hline Costa Rica & 10.92 & 6.09 & 9.75 & 6.33 & -1.17 & 0.23 \\
\hline Hungary & 2.28 & 2.00 & 1.94 & 1.53 & -0.34 & -0.47 \\
\hline Mexico & 1.47 & 1.60 & 1.09 & 1.19 & -0.39 & -0.40 \\
\hline Poland & 0.86 & 0.78 & 0.81 & 0.74 & -0.05 & -0.04 \\
\hline Turkey & 3.14 & 1.81 & 2.94 & 1.76 & -0.20 & -0.05 \\
\hline Argentina & 6.92 & 5.88 & 6.85 & 5.76 & -0.07 & -0.11 \\
\hline Brazil & 3.30 & 9.12 & 3.19 & 9.14 & -0.11 & 0.01 \\
\hline Bulgaria & 3.50 & 4.88 & 3.13 & 4.46 & -0.38 & -0.42 \\
\hline Cambodia & 4.02 & 4.29 & 3.09 & 3.43 & -0.92 & -0.86 \\
\hline China (People's Republic of) & 1.19 & 0.44 & 1.03 & 0.41 & -0.16 & -0.03 \\
\hline Croatia & 1.92 & 1.65 & 1.82 & 1.66 & -0.11 & 0.01 \\
\hline India & 1.47 & 0.96 & 1.35 & 0.82 & -0.12 & -0.13 \\
\hline Indonesia & 2.08 & 2.13 & 1.93 & 2.00 & -0.14 & -0.13 \\
\hline Kazakhstan & 2.30 & 1.28 & 2.46 & 1.33 & 0.15 & 0.05 \\
\hline Lao People's Democratic Rep. & 6.66 & 8.31 & 6.19 & 7.58 & -0.48 & -0.73 \\
\hline Malaysia & 2.35 & 0.70 & 1.58 & 0.55 & -0.77 & -0.15 \\
\hline Morocco & 5.13 & 5.29 & 4.26 & 4.33 & -0.87 & -0.96 \\
\hline Myanmar & 14.48 & 11.86 & 12.35 & 10.67 & -2.13 & -1.19 \\
\hline Peru & 1.76 & 1.25 & 1.71 & 1.16 & -0.05 & -0.09 \\
\hline Philippines & 5.63 & 2.54 & 4.80 & 2.15 & -0.83 & -0.38 \\
\hline Romania & 1.59 & 3.03 & 1.35 & 2.85 & -0.23 & -0.17 \\
\hline Russian Federation & 0.24 & 1.66 & 0.25 & 1.76 & 0.00 & 0.10 \\
\hline South Africa & 1.49 & 1.26 & 1.46 & 1.34 & -0.03 & 0.08 \\
\hline Thailand & 1.23 & 1.09 & 1.03 & 0.86 & -0.20 & -0.23 \\
\hline Tunisia & 1.01 & 2.08 & 0.76 & 1.53 & -0.25 & -0.55 \\
\hline Vietnam & 3.08 & 4.11 & 2.86 & 3.22 & -0.22 & -0.90 \\
\hline
\end{tabular}

Source: OECD, Trade in Value-added (TiVA) 2021 ed., http:/ / stats.oecd.org/. (accessed on 30 November 2021).

The comparison of RCA indices calculated on the basis of the gross value of exports and domestic value added allowed the identification of those countries for which integration within global production networks had a significant impact on their comparative advantage. In 1995, the positive impact of foreign value added on the formation of a comparative advantage could be demonstrated only in three countries (Chile, Russia and Kazakhstan). In 2018, FVA positively influenced the comparative advantage of 7 economies (Chile, Costa Rica, Brazil, Croatia, Kazakhstan, Russia and South Africa). Nevertheless, only in two cases (Brazil and Russia) did the foreign value added increase the RCA indices, and thus the improvement of their comparative advantage relative to 1995. In other economies, the FVA only slowed down the process of losing comparative advantage.

The second product group analyzed is food products, beverages and tobacco. When assessing the formation of the revealed comparative advantage in the analyzed group of economies, we can indicate several regularities. For the RCA indices calculated on the gross value of exports in 1995, 18 out of 28 analyzed countries had a comparative advantage, and by 2018 the number had increased to 23 . The value of RCA indices was in most countries lower than in the previously analyzed group of unprocessed agricultural products. In 1995, South and Central American countries had the highest comparative advantage: Costa Rica (6.36), Argentina (4.57), Brazil (4.44) and Peru (3.82). Whereas in 2018 we can again consider South and Central American countries as the most competitive in the export of the 
studied group of products: Argentina (6.20), Costa Rica (3.82), Chile (3.29) and Brazil (3.25), joined by Asian countries: Indonesia (3.92) and Myanmar (3.88). In the years 1995-2018, RCA indices increased in 19 out of 28 analyzed economies (Table 6), and in 5 countries the increases were significant enough to allow for a comparative advantage (RCA > 1). Despite the reduction of the comparative gap in 4 economies (Mexico, Kazakhstan, Romania and Russia), it was not possible to achieve an advantage.

Table 6. RCA based on national added value in food products, beverages and tobacco.

\begin{tabular}{|c|c|c|c|c|c|c|}
\hline & \multicolumn{2}{|c|}{ DVA } & \multicolumn{2}{|c|}{ GE } & \multicolumn{2}{|c|}{ GE-DVA } \\
\hline & 1995 & 2018 & 1995 & 2018 & 1995 & 2018 \\
\hline Chile & 2.77 & 3.21 & 2.86 & 3.29 & 0.09 & 0.08 \\
\hline Colombia & 0.82 & 2.68 & 0.83 & 2.75 & 0.01 & 0.07 \\
\hline Costa Rica & 6.55 & 3.62 & 6.36 & 3.82 & -0.19 & 0.21 \\
\hline Hungary & 1.60 & 1.28 & 1.42 & 1.12 & -0.19 & -0.16 \\
\hline Mexico & 0.53 & 0.92 & 0.54 & 0.80 & 0.02 & -0.12 \\
\hline Poland & 1.31 & 2.38 & 1.22 & 2.28 & -0.10 & -0.09 \\
\hline Turkey & 1.24 & 1.33 & 1.20 & 1.28 & -0.04 & -0.05 \\
\hline Argentina & 4.62 & 6.35 & 4.57 & 6.20 & -0.05 & -0.15 \\
\hline Brazil & 4.51 & 3.28 & 4.44 & 3.25 & -0.07 & -0.02 \\
\hline Bulgaria & 1.25 & 1.74 & 1.16 & 1.83 & -0.09 & 0.09 \\
\hline Cambodia & 0.80 & 1.23 & 0.77 & 1.14 & -0.03 & -0.08 \\
\hline China (People's Republic of) & 0.94 & 0.76 & 0.85 & 0.71 & -0.08 & -0.05 \\
\hline Croatia & 1.82 & 1.28 & 1.85 & 1.36 & 0.03 & 0.08 \\
\hline India & 1.51 & 1.81 & 1.39 & 1.61 & -0.12 & -0.20 \\
\hline Indonesia & 1.33 & 4.10 & 1.28 & 3.92 & -0.05 & -0.18 \\
\hline Kazakhstan & 0.29 & 0.49 & 0.30 & 0.51 & 0.02 & 0.02 \\
\hline Lao People's Democratic Rep. & 0.70 & 2.05 & 0.72 & 1.95 & 0.01 & -0.09 \\
\hline Malaysia & 2.44 & 2.34 & 1.91 & 2.27 & -0.54 & -0.07 \\
\hline Morocco & 2.30 & 3.02 & 2.10 & 2.66 & -0.19 & -0.36 \\
\hline Myanmar & 3.66 & 4.35 & 3.12 & 3.88 & -0.54 & -0.46 \\
\hline Peru & 3.64 & 0.99 & 3.82 & 1.00 & 0.18 & 0.01 \\
\hline Philippines & 2.10 & 1.79 & 2.03 & 1.62 & -0.07 & -0.17 \\
\hline Romania & 0.43 & 0.71 & 0.37 & 0.65 & -0.06 & -0.05 \\
\hline Russian Federation & 0.48 & 0.55 & 0.52 & 0.60 & 0.04 & 0.05 \\
\hline South Africa & 0.64 & 1.87 & 0.61 & 1.79 & -0.03 & -0.08 \\
\hline Thailand & 3.31 & 3.14 & 2.97 & 2.67 & -0.34 & -0.47 \\
\hline Tunisia & 1.03 & 2.67 & 0.94 & 2.45 & -0.09 & -0.22 \\
\hline Vietnam & 3.13 & 3.25 & 3.00 & 2.71 & -0.13 & -0.55 \\
\hline
\end{tabular}

After the use of an alternative calculation method based on domestic value added, the group of countries with the highest comparative advantage in 1995 included Costa Rica (6.55), Argentina (4.62), Brazil (4.51), Peru (3.64) and Myanmar (3.66). In 2018, apart from the countries of South and Central America: Argentina (6.35), Costa Rica (3.62), Brazil (3.28) and Chile (3.21), Asian countries had the largest comparative advantage: Myanmar (4.35), Indonesia (4.10), Vietnam (3.25) and Thailand (3.14). The improvement in comparative advantage between 1995 and 2018 occurred in 19 out of 28 economies, with Indonesia and Colombia having the greatest increase in the RCA index. The improvement in the RCA indices in Colombia, Cambodia, Lao and South Africa was so significant that they moved from a group of countries which in the mid-1990s had a comparative gap, to a group of countries with an advantage. Despite the increase in the RCA indexes, Mexico, Kazakhstan, Romania and Russia still have a comparative gap in the export of food products, beverages and tobacco.

Assessing the role of foreign value added in the creation of comparative advantage, we indicate 6 countries for which the impact was positive. In Chile and Colombia competitiveness has improved, in Russia and Kazakhstan the comparative gap has narrowed. In 
Croatia, FVA has slowed the loss of competitiveness. In Peru, on the other hand, the large decline in the FVA share between 1995 and 2018 resulted in a significant deterioration in export competitiveness.

Usually, the importance of FVA in creating a country's comparative advantage in global exports increases as the degree of product processing, level of technological advancement and capital intensity increases. This partly explains the relatively low impact of foreign value added on agricultural trade competitiveness. This is due to the low possibility of fragmentation of the production process of agricultural raw materials and processed food, much less than, for example, in the automotive or electronics industries. The following factors also played an important role in the limited impact of integration within global chains on the competitiveness of the analyzed group of countries in world agricultural exports:

(1) ongoing structural transformations consisting of a decrease in the share of the agricultural sector in generating GDP and employment for the benefit of the processing industry and/or services.

(2) high concentration of sales of agricultural products on the domestic market.

\subsection{Discussion}

The main conclusions of the study are confirmed by the published results of other authors. Regarding the increasing trend in exports of food and agricultural raw materials by developing countries, similar findings were obtained by Bojnec, Ferto and Fogaras (2014), whose study focused on Brazil and India [77]. In contrast, Schwartz et al. (2015) noted that not only has trade in agri-food commodities expanded rapidly, but its structure has additionally changed significantly, with important implications, especially for developing economies [78]. Szczepaniak (2018) pointed out the positive impact of integration processes on the development of foreign trade in food products [79]. Moreover, Athukorala (2018) noted that operational linkages between cooperators generally intensified foreign trade processes [80].

Another important finding of the study is that the share of foreign value added in the exports of agriculture, hunting, forestry and fishing varied strongly between countries. Bojnec and Ferto (2012) showed a positive effect of an increased number of varieties of agri-food products on export growth, but less on the diversification of higher value-added food products [81]. It is even a frequent phenomenon that the share of products with higher added value decreases, despite the increase in exports, which is due to the increase in the share of basic agricultural raw materials with low added value [82]. This research is supported by the results of Shafi, Muchie and Sedebo (2021) who showed that the growth in the value of real exports and imports of the agro-processing sub-sector of manufacturing industry tends to decline in each specified period [83].

The linking of global value chains to the measurement of competitiveness was carried out in the research of Mashabela and Vink (2008). The authors proved that participation in global value chains increases the competitiveness of the participant in the international arena [84]. Oro and Pritchard (2011) on the other hand, showed that the necessary restructuring in food resulted additionally from the desire to obtain a foreign competitive advantage [85]. Intensifying global competition means that even in the local market and in retail, an increase in demanding customers creates the requirement of more attention focused to seeking and maintaining a sustainable competitive advantage [86]. Further development of the discussed research can be found in the results of Gachukia and Muturi (2017). Competitive strategies play a role in the configuration of global value chains [87]. However, as Ćejvanović and Potrebić (2018) note, agriculture and agri-food chains have a number of weaknesses that reduce their competitiveness in the international market [88]. The main weaknesses are that the uncertainty and complexity of the environment is exacerbated in food supply chains, which is when approaches move from production with undifferentiated food commodities to products with differentiated value added [89]. Not all countries participating in foreign trade have been able to integrate into global value chains with equal success. This is largely true of trade in food and other agribusiness industry 
commodities. As shown by Şerbănel's (2014) research, African and Latin American countries are still seeking better access to global value chains by increasing the competitiveness of their industries and products [90]. LDC countries face similar problems. Therefore, international organizations recommend the necessity to draw the attention of authorities to the improvement of public order and taxation systems in these countries in order to increase the competitiveness of these markets. This will then increase the willingness to use agricultural raw materials from these countries and, as a result, improve their share in global value chains [91]. The exact indicators of the discussed values were observed by Fujita (2013), showing that in developed countries, the average imported value added in exports amounts to $31 \%$, assuming much lower values in developing countries. However, this indicator does not exceed $14 \%$ for LDC countries [92]. These conclusions are also confirmed by other authors, pointing to the need to support and promote domestic food producers by improving their competitiveness on the international market, which is also expressed in the increase in export value added [59,93-103]. Moreover, in this context, it is important that at the level of individual enterprises, who export their products on international agricultural markets, intensification of activities improves their long-term competitiveness. Felzensztein and Gimmon (2014) proved that management should improve value added through differentiation, diversification of offerings and implementation of innovative marketing strategies [104]. It should also be remembered that the production and generation sectors were in the past considered to generate the highest added value. In a modern economy, research should also include R\&D, the infrastructure of enterprises and their logistics, as well as marketing activities as a source of added value. Jun and Rowley (2019) argue that even a change in organizational structure affects the added value that interacts with the international competitiveness of the entity [105].

\section{Conclusions}

The analysis of the impact of integration within global value-added chains on the comparative advantage of developing countries in world agricultural exports in the years 1995-2018, carried out in the article, allows for the formulation of several conclusions. Firstly, from the mid-1990s, we can observe a clear trend consisting of the growing importance of a group of developing countries in the world exports of food and agricultural raw materials. In 1995, their share in food exports were $31.2 \%$ and increased by $9 \%$ to $40.1 \%$ in 2020. In the same period, the share of developing countries in the export of agricultural raw materials increased by $7.6 \%$, from $30.6 \%$ to $38.2 \%$. In both cases, the period of the fastest growth in participation was between the years 2000-2010. After 2010, the share of developing countries in food exports stabilized, and in the exports of agricultural raw materials in 2011-2015 there was a characteristic downward trend, followed by a period of relative stabilization.

Secondly, changes in the position of developing countries in the global exports of agricultural products take place in response to many factors, among which a significant factor is the degree of integration within global value chains, measured by the share of foreign value added in gross exports. The period of highest growth in the share of developing countries, was additionally marked by the observation of the highest increase in FVA in their exports. After 2010, the strength of production links weakened and the share of world agricultural trade declined. Thus, we can positively verify hypothesis 1 . The increase in the share of foreign value added in the gross exports of agricultural commodities of developing countries has been an important factor in strengthening their export position in this sector. Meanwhile, the importance of FVA in the development of agricultural exports of developing countries has varied between regions.

We can indicate that the strongest links within global value chains occurred in the developing countries of Central and Eastern Europe and Asia. The European chains were also most stable and the changes in the share of foreign value added were the smallest. Value chains in Latin America and Asia were less stable, which was reflected in relatively high fluctuations in their share in global agricultural exports. 
The assessment of the impact of foreign value added on the achieved comparative advantage in global agricultural exports was carried out on the basis of RCA indices calculated by two methods: classically based on the value of gross exports and on the basis of data taking into account only domestic value added. In the case of agriculture, hunting, forestry and fishing, FVA had a positive impact on the development of the RCA indices in a relatively narrow group of economies. In 2018, only in Chile, Costa Rica, Brazil, Croatia, Kazakhstan, Russia and South Africa, were the level of RCA indices calculated on the basis of gross exports higher than those calculated on the basis of DVA. At the same time, from the aforementioned group of countries, only in Brazil and Russia did FVA cause an increase in comparative advantage, and in the remaining economies the positive contribution of FVA only slowed down the process of comparative advantage loss. In the food products, beverages and tobacco group, the positive impact of FVA on the shaping of a comparative advantage could be demonstrated in five countries, but the significance varied. In Chile and Colombia, competitiveness improved, in Russia and Kazakhstan, the comparative gap narrowed, and in Croatia, the process of competitiveness loss slowed down. Thus, we can positively verify hypothesis 2 only in a narrow group of developing countries, and for most economies the verification is negative. This is mainly due to the structural changes taking place in the analyzed group of countries, consisting of the decline in the importance of the agricultural sector. The verification of hypothesis 3 is also negative. Numerous studies evaluating the impact of foreign value added on the shaping of comparative advantage have shown that the importance of integration within global value chains increases with increasing product complexity. However, such analyses were limited only to the processing industry, where such a relationship is clear. In agricultural production, FVA in most developing countries does not have a significant impact on the shaping of the comparative advantage, regardless of whether the analysis concerns agricultural raw materials or food.

The results obtained in the article may be a starting point for further research in the area of global value chains in agricultural trade. Firstly, the publication of newer databases (OECD-WTO), in addition to other development projects (ADB), may allow a more detailed analysis in terms of subject matter (including more disaggregated data for a larger number of product categories), geographical data and time. Moreover, the competitiveness assessment can be complemented by other indicators, such as CRCA and the Lafay Index. Unfortunately, the currently available data do not allow for a more comprehensive analysis.

Author Contributions: Conceptualization, T.B.; theoretical framework, A.B., T.B.; methodology, T.B.; results analysis, A.B., T.B.; discussion, A.B., T.B.; conclusions, T.B. All authors have read and agreed to the published version of the manuscript.

Funding: This research received no external funding.

Institutional Review Board Statement: Not applicable.

Informed Consent Statement: Not applicable.

Conflicts of Interest: The authors declare no conflict of interest.

\section{References}

1. UN Recognition of the Least Developed Countries. Available online: https://unctad.org/topic/least-developed-countries/ recognition (accessed on 4 January 2022).

2. Least Developed Countries. 2021. Available online: https://worldpopulationreview.com/country-rankings/least-developedcountries (accessed on 4 January 2022).

3. United Nations. United Nations Conference on Trade and Development. World Economic Situation and Prospects 2021; United Nations: New York, NY, USA, 2021; ISBN 978-92-1-109182-3.

4. Kuepper, J. What Is a Developing Country? The Balance: New York, NY, USA, 2021.

5. Prabhakar, A.C.; Erokhin, V.; Kaur, G. Regional Trade and Development Strategies in the Era of Globalization; IGI Global: Pennsylvania, PA, USA, 2019; ISBN 1-79981-732-6. 
6. Foster, N.; Stehrer, R.; Timmer, M. International Fragmentation of Production, Trade and Growth: Impacts and Prospects for EU Member States; Economic Papers; European Commission, Directorate General for Economic and Financial Affairs: Brussels, Belgium, 2013; ISBN 978-92-79-28566-0.

7. Hoekman, B. Adding Value. Financ. Dev. 2013, 50, $22-24$.

8. Dai, L. The Comparative Advantage of Nations: How Global Supply Chains Change Our Understanding of Comparative Advantage. Mossavar-Rahmani Cent. Bus. Gov. Assoc. Work. Pap. Ser. 2013, 15, 1-81.

9. Dean, J.M. Measuring Value-Added Trade: What's in It for Developing Countries? In Trade in Value Added Developing New Measures of Cross-Border Trade; The International Bank for Reconstruction and Development/The World Bank: Washington, DC, USA, 2013; ISBN 978-1-907142-58-1.

10. Hopkins, T.K.; Wallerstein, I. Patterns of Development Modern World-System. Review 1977, 1, 111-145.

11. Hopkins, T.K.; Wallerstein, I. Commodity Chains in the World-Economy Prior to 1800. Review 1986, 10, 157-170.

12. Gereffi, G.; Korzeniewicz, M.; Korzeniewicz, R.P. Introduction: Global Commodity Chains. In Commodity Chains and Global Capitalism; Gereffi, G., Korzeniewicz, M., Eds.; Praeger: London, UK, 1994; pp. 1-14.

13. Gereffi, G.; Humphrey, J.; Sturgeon, T. The Governance of Global Value Chains. Rev. Int. Polit. Econ. 2005, 12, 78-104. [CrossRef]

14. Simola, H. The Impact of Covid-19 on Global Value Chains. BOFIT Policy Brief 2021, 1-32. [CrossRef]

15. Antràs, P. Conceptual Aspects of Global Value Chains. World Bank Econ. Rev. 2020, 34, 551-574. [CrossRef]

16. World Trade Organization. Recent Patterns of Global Production and GVC Participation. In Global Value Chain Development Report 2019; WTO: Geneva, Switzerland, 2019; pp. 9-43. ISBN 978-92-870-5005-2.

17. Wang, Z.; Wei, S.-J.; Yu, X.; Zhu, K. Measures of Participation in Global Value Chains and Global Business Cycles; National Bureau of Economic Research: Cambridge, MA, USA, 2017; pp. 1-35.

18. Henderson, J.; Dicken, P.; Hess, M.; Coe, N.; Yeung, H.W.-C. Global Production Networks and the Analysis of Economic Development. Rev. Int. Polit. Econ. 2002, 9, 436-464. [CrossRef]

19. Coe, N.M.; Hess, M.; Yeungt, H.W.-C.; Dicken, P.; Henderson, J. “Globalizing” Regional Development: A Global Production Networks Perspective. Trans. Inst. Br. Geogr. 2004, 4, 468-484. [CrossRef]

20. Cuéllar, M.-F.; Lazarus, D.; Falcon, W.P.; Naylor, R.L. Institutions, Interests, and Incentives in American Food and Agriculture Policy. In The Evolving Sphere of Food Security; Oxford University Press: New York, NY, USA, 2014; ISBN 978-0-19-935405-4.

21. A Multi-Billion-Dollar Opportunity-Repurposing Agricultural Support to Transform Food Systems; FAO: Rome, Italy, 2021; ISBN 978-92-5-134917-5.

22. Cahill, C.; Legg, W. Estimation of Agricultural Assistance Using Producer And Consumer Subsidy Equivalents: Theory And Practice. OECD Econ. Stud. 1990, 13, 13-42.

23. Briones Alonso, E.; Swinnen, J. Who Are the Producers and Consumers? Value Chains and Food Policy Effects in the Wheat Sector in Pakistan. Food Policy 2016, 61, 40-58. [CrossRef]

24. Swinnen, J.; Olper, A.; Vandevelde, S. From Unfair Prices to Unfair Trading Practices: Political Economy, Value Chains and 21st Century Agri-food Policy. Agric. Econ. 2021, 52, 771-788. [CrossRef]

25. Seremak, J.B. Monitoring and analysis of changes in the Polish food chain. In Economic and Social Conditions for the Development of the Polish Agro-Food Economy after Poland's Accession to the European Union (Synthesis); Institute of Agricultural and Food Economics-National Research Institute: Warsaw, Poland, 2010; pp. 83-95. ISBN 978-83-7658-124-8.

26. Stanisław, K. Sustainable Agriculture in the Era of Globalization. (45), Sustainable Agriculture in the Globalization Era: Threats and Opportunities; Institute of Agricultural and Food Economics-National Research Institute: Warsaw, Poland, 2018; ISBN 978-83-7658-741-7.

27. World Bank. Trading for Development in the Age of Global Value Chains; World Development Report; World Bank: Washington, DC, USA, 2020; ISBN 978-1-4648-1495-2.

28. Mundt, A. Bundeskartellamt Imposes Fines on Harbour Towage Service Providers. Press Release Bundeskartellamt. 2017. Available online: https://www.bundeskartellamt.de/SharedDocs/Publikation/EN/Pressemitteilungen/2017/18_12_2017_ Hafenschlepper.pdf?_blob=publicationFile\&v=4 (accessed on 30 November 2021).

29. Thacher, S.; Barlet, L. Global Cartel Enforcement Report. 2019, pp. 1-7. Available online: https://www.stblaw.com/docs/defaultsource/Publications/globalcartelenforcementreport_january2019.pdf (accessed on 30 November 2021).

30. FTC's Bureau of Competition Launches Task Force to Monitor Technology Markets. Available online: https://www.ftc.gov/newsevents/press-releases/2019/02/ftcs-bureau-competition-launches-task-force-monitor-technology (accessed on 22 November 2021).

31. Faße, A.; Grote, U.; Winter, E. Value Chain Analysis Methodologies in the Context of Environment and Trade Research. Available online: https:/ / www.econstor.eu/bitstream/10419/37104/1/609241915.pdf (accessed on 30 November 2021).

32. Kaplinsky, R.; Morris, M. A Handbook for Value Chain Research; Institute of Development Studies: Brighton, UK, 2002.

33. Bellù, L.G. Value Chain Analysis for Policy Making: Methodological Guidelines and Country Cases for a Quantitative Approach. EASYPol Ser. 2013, 129, 1-178.

34. Bertazzoli, A.; Samoggia, A.; Ghelfi, R.; Rivaroli, S. Value Sharing and Food System Dynamics for Milk, Tomato and Cereals Food Chains. Int. J. Food Syst. Dyn. 2010, 4, 330-341. [CrossRef]

35. Porter, M.E. Competitive Advantage Creating Sustaining Performance; Free Press: New York, NY, USA, 1985.

36. Feller, A.; Shunk, D.D.; Callarman, D.T. Value Chains Versus Supply Chains. Bus. Process Trends 2006, 1, 1-7.

37. Gereffi, G. The Organization of Buyer-Driven Global Commodity Chains: How U. S. Retailers Shape Overseas Production Networks. In Commodity Chains and Global Capitalism; Greenwood Press: Westport, Ireland, 1994; pp. 95-122. ISBN 0-275-94573-1. 
38. Trienekens, J.H. Agricultural Value Chains in Developing Countries A Framework for Analysis. Int. Food Agribus. Manag. Rev. 2011, 14, 32 .

39. Dollar, D.; Kidder, M. Institutional Quality and Participation in Global Value Chains. In Measuring and Analyzing the Impact of GVCs on Economic Development; World Bank: Washington, DC, USA, 2017.

40. Ge, Y.; Dollar, D.; Yu, X. Institutions and Participation in Global Value Chains: Evidence from Belt and Road Initiative. China Econ. Rev. 2020, 61, 101447. [CrossRef]

41. Lee, S. Three Essays in Applied Microeconomics. Ph.D. Dissertation, University of Minnesota Digital Conservancy, Minnesota, MN, USA, 2020.

42. Tinta, A.A.; Sarpong, D.B.; Ouedraogo, I.M.; Al Hassan, R.; Mensah-Bonsu, A.; Ebo Onumah, E. The Effect of Integration, Global Value Chains and International Trade on Economic Growth and Food Security in ECOWAS. Cogent Food Agric. 2018, $4,1465327$. [CrossRef]

43. Yanikkaya, H.; Karaboga, H.; Altun, A. Implications of Participation in Global Value Chains for International Trade Network. Appl. Econ. Lett. 2021, 28, 1169-1173. [CrossRef]

44. Amador, J.; Cabral, S. Global Value Chains Surveying Drivers And Measures. 2014. Available online: https://www.ecb.europa. eu/pub/pdf/scpwps/ecbwp1739.en.pdf (accessed on 20 January 2022).

45. Christova-Balkanska, I. COVID-19 Implications on Global Value Chains in Bulgaria and Romania. Glob. Econ. Obs. 2021, 9, 39-47.

46. Zylberberg, E. Bloom or Bust? A Global Value Chain Approach to Smallholder Flower Production in Kenya. J. Agribus. Dev. Emerg. Econ. 2013, 3, 4-26. [CrossRef]

47. World Trade Organization. Should High Domestic Value Added in Exports Be an Objective of Policy? In Global Value Chain Development Report 2019; WTO: Geneva, Switzerland, 2019; pp. 141-153. ISBN 978-92-870-5005-2.

48. Taglioni, D.; Winkler, D. Making Global Value Chains Work for Development; Trade and Development Series; World Bank: Washington, DC, USA, 2016; ISBN 978-1-4648-0157-0.

49. Minten, B.; Randrianarison, L.; Swinnen, J.F.M. Global Retail Chains and Poor Farmers: Evidence from Madagascar. World Dev. 2009, 37, 1728-1741. [CrossRef]

50. Cattaneo, O.; Gereffi, G.; Miroudot, S.; Taglioni, D. Joining, Upgrading and Being Competitive in Global Value Chains: A Strategic Framework; Policy Research Working Papers; The World Bank: Washington, DC, USA, 2013.

51. Swinnen, J.; Vandeplas, A. Price Transmission and Market Power in Modern Agricultural Value Chains. LICOS Discuss. Pap. 2014, 347, 1-30. [CrossRef]

52. Swinnen, J.F.M. Economics and Politics of Food Standards, Trade, and Development. Agric. Econ. 2016, 47, 7-19. [CrossRef]

53. Greenville, J.; Kawasaki, K.; Beaujeu, R. How Policies Shape Global Food and Agriculture Value Chains. OECD Food Agric. Fish. Pap. 2017, 100. [CrossRef]

54. Humphrey, J.; Memedovic, O. Global Value Chains in the Agrifood Sector; Industrial Development Organization: Vienna, Austria, 2006

55. Gereffi, G.; Lee, J. Why the World Suddenly Cares about Global Supply Chains. J. Supply Chain Manag. 2012, 48, 24-32. [CrossRef]

56. Sanguinet, E.R.; Alvim, A.M.; Atienza, M. Trade Agreements and Participation in Global Value Chains: Empirical Evidence from Latin America. World Econ. 2021. [CrossRef]

57. Bair, J.; Mahutga, M.; Werner, M.; Campling, L. Capitalist Crisis in the "Age of Global Value Chains". Environ. Plan. Econ. Space 2021, 53, 1253-1272. [CrossRef]

58. Zhang, Q.-P. Independent Growth of China's Proceeding Trade in the Global Value Chains; Atlantis Press: Atlantis, USA, 2017; pp. 267-269.

59. Balié, J.; Del Prete, D.; Magrini, E.; Montalbano, P.; Nenci, S. Does Trade Policy Impact Food and Agriculture Global Value Chain Participation of Sub-Saharan African Countries? Am. J. Agric. Econ. 2019, 101, 773-789. [CrossRef]

60. Hidayati, D.R.; Garnevska, E.; Childerhouse, P. Sustainable Agrifood Value Chain-Transformation in Developing Countries. Sustainability 2021, 13, 12358. [CrossRef]

61. Sulewski, P.; Kłoczko-Gajewska, A.; Sroka, W. Relations between Agri-Environmental, Economic and Social Dimensions of Farms Sustainability. Sustainability 2018, 10, 4629. [CrossRef]

62. Karadimitropoulou, A. Advanced Economies and Emerging Markets: Dissecting the Drivers of Business Cycle Synchronization. J. Econ. Dyn. Control 2018, 93, 115-130. [CrossRef]

63. Bečvářová, V. Issues of Competitiveness of the Present Agriculture. Agric. Econ.-Czech 2008, 54, 399-405. [CrossRef]

64. Nugroho, A.D.; Bhagat, P.R.; Magda, R.; Lakner, Z. The Impacts of Economic Globalization on Agricultural Value Added in Developing Countries. PLoS ONE 2021, 16, e0260043. [CrossRef]

65. Białowąs, T.; Wojtas, M. The Role of Foreign Value Added in Creating Poland's Comparative Advantage in World Merchandise Exports. Ann. Univ. Mariae Curie-Skłodowska Sect. H Oeconomia 2014, 48, 31-40. [CrossRef]

66. Choi, N.; Park, S. Comparative Advantage of Value Added in Exports: The Role of Offshoring and Transaction Costs. KIEP Res. Pap. Work. Pap. 2016. [CrossRef]

67. Kordalska, A.; Olczyk, M. CEE Trade in Services: Value Added Versus Gross Terms Approaches. 2018. Available online: https:/ / www.econstor.eu/bitstream/10419/202496/1/1018817581.pdf (accessed on 30 November 2021).

68. Deb, K.; Hauk, W.R. RCA Indices, Multinational Production and the Ricardian Trade Model. Int. Econ. Econ. Policy 2017, 14, 1-25. [CrossRef]

69. Grater, S. Comparative Advantage of Value-Added Services: The Case of South Africa. Manag. Glob. Transit. 2014, 12, 279-295. 
70. OECD. Global Value Chains in Agriculture and Food: A Synthesis of OECD Analysis. OECD Food Agric. Fish. Pap. 2020, 139. [CrossRef]

71. Inomata, S. Analytical Frameworks for Global Value Chains: An Overview. In Global Value Chain Development Report 2017: Measuring and Analyzing the Impact of GVCs on Economic Development; The World Bank: Washington, DC, USA, 2017 ; pp. 15-35.

72. Balassa, B. Trade Liberalization and Revealed Comparative Advantage. Manch. Sch. Econ. Soc. Stud. 1995, 32, 99-123.

73. UNCTAD Eora Trade In Value Added Database. 2015. Available online: http:/ / www.worldmrio.com/ (accessed on 30 November 2021).

74. WIOD 2016 Release. 2016. Available online: http:/ / www.wiod.org/release16/ (accessed on 30 November 2021).

75. OECD-WTO Trade in Value Added. Available online: http:/ / stats.oecd.org/ (accessed on 30 November 2021).

76. Division on International Trade and Commodities (DITC). United Nations Conference on Trade and Development (UNCTAD) Key Statistics and Trends in International Trade 2020-2021. Available online: https:/ / unctad.org/system/files / official-document/ ditctab2020d4_en.pdf (accessed on 30 November 2021).

77. Bojnec, S.; Ferto, I.; Fogarasi, J. Quality of Institutions and the BRIC Countries Agro-Food Exports. China Agric. Econ. Rev. 2014, 6, 379-394. [CrossRef]

78. Schwarz, J.; Mathijs, E.; Maertens, M. Changing Patterns of Global Agri-Food Trade and the Economic Efficiency of Virtual Water Flows. Sustainability 2015, 7, 5542-5563. [CrossRef]

79. Szczepaniak, I. Comparative Advantages in Polish Export to the European Union-Food Products vs Selected Groups of Non-Food Products. Oeconomia Copernic. 2018, 9, 287-308. [CrossRef]

80. Athukorala, P. Global Productions Sharing and Local Entrepreneurship in Developing Countries: Evidence from Penang Export Hub, Malaysia. Asia Pac. Policy Stud. 2017, 4, 180-194. [CrossRef]

81. Bojnec, S.; Ferto, I. Agro-Food Exports Variety from the Central and Eastern European Countries. Agric. Econ.-Zemed. Ekon. 2012, 58, 1-9. [CrossRef]

82. Petril'ák, M.; Horská, E.; Šumichrast, J.; Palkovič, J. Comparison of Slovak Dairy Products with and without Added Value Sold by Commercial Chains; Aleksandras Stulginskis University: Kaunas, Lithuania, 2017; pp. 1238-1243.

83. Shafi, A.A.; Muchie, M.; Sedebo, G.T. South Africa's Agro Processing Trade in Value Added, Global Value Chains (GVCs) Perspective. Afr. J. Sci. Technol. Innov. Dev. 2021, 1-10. [CrossRef]

84. Mashabela, T.E.; Vink, N. Competitive Performance of Global Deciduous Fruit Supply Chains: South Africa versus Chile. Agrekon 2008, 47, 240-257. [CrossRef]

85. Oro, K.; Pritchard, B. The Evolution of Global Value Chains: Displacement of Captive Upstream Investment in the Australia-Japan Beef Trade. J. Econ. Geogr. 2011, 11, 709-729. [CrossRef]

86. Yan, H.; Adebanjo, D.; Mahoney, F. Competitive Advantage in Food Retail Strategy and Supply Chain-An Analysis of the UK and Chinese Markets. IEEE Int. Eng. Manag. Conf. IEEE Cat No04CH37574 2004, 1, 90-93. [CrossRef]

87. Gachukia, M.K.W.; Muturi, W.M. Identifying Global Value Chain Governance Determinants in Kenya's Horticultural Oriented Export Sector by Nonlinear Principal Component Analysis. Int. J. Food Syst. Dyn. 2017, 8, 317-335. [CrossRef]

88. Ćejvanović, F.; Potrebić, V. Value Chain of Agricultural-Food Products. Proc. IAE Sci. Meet. 2018, 1, $216-229$.

89. Trienekens, J.; van Velzen, M.; Lees, N.; Saunders, C.; Pascucci, S. Governance of Market-Oriented Fresh Food Value Chains: Export Chains from New Zealand. Int. Food Agribus. Manag. Rev. 2018, 21, 249-268. [CrossRef]

90. Şerbănel, C.I. New Coordinates and Challenges: Moving up the Value Chain. A Macroeconomic Perspective. Stud. Bus. Econ. 2014, 9, 168-180.

91. United Nations Conference on Trade and Development (UNCTAD); OECD. WTO Implications of Global Value Chains for Trade, Investment, Development and Jobs. 2013. Available online: https://unctad.org/system/files/official-document/unctad_oecd_ wto_2013d1_en.pdf (accessed on 30 November 2021).

92. Fujita, M. FDI and Trade in GVCs. Preliminary Findings on Investment and Value Added Trade in the Global Economy. 2013. Available online: https://www.cepal.org/sites/default/files/events/files/presentation_masataka_fujita_unctad.pdf (accessed on 30 November 2021).

93. Bojnec, Š.; Ferto, I. Agri-Food Export Competitiveness in European Union Countries. JCMS J. Common Mark. Stud. 2015, 55, 476-492. [CrossRef]

94. Buturac, G.; Lovrinčević, Ž.; Mikulić, D. Export Competitiveness of The Croatian Food Industry. Argum. Oeconomica 2018, 2, 136-155. [CrossRef]

95. Sikdar, C.K. Global Value Chain and Effects of Trade Policy Instruments-A Case of India. In Applications of the Input-Output Framework; Springer: Berlin/Heidelberg, Germany, 2018; pp. 293-314. [CrossRef]

96. Touboulic, A.; Walker, H.L. Love Me, Love Me Not: A Nuanced View on Collaboration in Sustainable Supply Chains. J. Purch. Supply Manag. 2015, 21, 178-191. [CrossRef]

97. Chen, H.; Xu, J. Value Added Decomposition of Chinese Provincial Exports and Its Assessment of True Comparative Advantage: A Case Study of Manufacturing in Jiangsu Province. Open J. Soc. Sci. 2019, 7, 380-399. [CrossRef]

98. Mizik, T. Agri-Food Trade Competitiveness: A Review of the Literature. Sustainability 2021, 13, 11235. [CrossRef]

99. Mizik, T.; Szerletics, Á.; Jámbor, A. Agri-Food Export Competitiveness of the ASEAN Countries. Sustainability 2020, $12,9860$. [CrossRef]

100. Mizik, T.; Gál, P.; Török, Á. Does Agricultural Trade Competitiveness Matter? The Case of the CIS Countries. AGRIS -Line Pap. Econ. Inform. 2020, 12, 61-72. [CrossRef] 
101. Mizik, T. Theory vs. Practice: Patterns of the ASEAN-10 Agri-Food Trade. Open Agric. 2021, 6, 152-167. [CrossRef]

102. Chen, K.; Xu, L.; Duan, Y. Ex-Post Competitiveness of China's Export in Agri-Food Products: 1980-1996. Agribusiness 2000, 16, 281-294. [CrossRef]

103. Xue, L.; Revell, B.J. Which Way Forward for China's Vegetable Exports? Br. Food J. 2009, 111, 26-43. [CrossRef]

104. Felzensztein, C.; Gimmon, E. Competitive Advantage in Global Markets: The Case of the Salmon Industry in Chile. Eur. Bus. Rev. 2014, 26, 568-587. [CrossRef]

105. Jun, I.W.; Rowley, C. Competitive Advantage and the Transformation of Value Chains over Time: The Example of a South Korean Diversified Business Group: 1953-2013. Bus. Hist. 2019, 61, 343-370. [CrossRef] 